\title{
Prognosys of dangerous geodynamic phenomena at the Kun-Manye field based on the analysis of digital elevation models
}

\author{
Vitaly Usikov ${ }^{1 *}$ \\ ${ }^{1}$ Mining Institute FEB RAS, 51 Turgenev st., Khabarovsk, 680000, Russia
}

\begin{abstract}
The Kuhn-Magnyo copper-nickel deposit is located in the southeast of the Aldan-Stanovoy shield. Based on the results of geological exploration, the object is assessed as promising. The ore field, within which the deposit is located, is confined to a complex junction of several regional tectonic structures. The area has an intensely dissected relief, increased seismicity. Therefore, an assessment of the possibility of dangerous geodynamic phenomena during its operation is required. This work describes its preliminary assessment based on the results of morphometry on digital elevation models (DEM). Several morphostructural elements have been identified that directly determine the geodynamics in the area of the earth's crust containing the deposit. The result of the study revealed a potential hazard.
\end{abstract}

Key words: geodynamics, geotectonics, digital elevation model, DEM, morphostructure, tectonic flow, relief, lineament

\section{Introduction}

The study area is located practically at the junction of three tectonic structural units: the Ilyun structural-facies zone of the Aldan region, the ledge of the early Archean base of the Stanovoy fold system and the Udsko-May structural-facies zone of the Stanovoy system. The area of the Kurumkansky ore field is confined to the junction of the Janinsky and Tuxanian blocks of the crystalline basement of the Aldan-Stanovoy shield. The Kun-Manyo field is located within several isolated, linearly elongated in the north-western direction areals of mafic-ultramafic intrusions. Ore bodies are composed of disseminated sulfide mineralization $[1,2]$. The intrusions belong to the Kunmanyon complex of gabbro-noritepyroxenite-peridotite formation [3,4]. The morphological features of ore bodies force at least part of the reserves to be mined underground. Considering the structural position and the significant vertical range of mineralization, the possibility of hazardous geodynamic phenomena should be assumed. The degree of study of the territory from the point of view of neotectonics and geodynamics is low. Therefore, a preliminary assessment was made based on the morphostructural features of the areas.

*Corresponding authors: v-i-usikov@yandex.ru 


\section{Methodology}

The technique is based on the construction and analysis of digital elevation models based on the SRTM30, GTOPO30, SRTM03 DEMs [5]. To identify global and regional structures, DEMs are used based on SRTM30, GTOPO30, containing the elevations of the relief, distributed on a regular grid with a step of 30 arc seconds (on the ground, this corresponds to a distance of about $1 \mathrm{~km}$ along the meridian and in detail to a scale of 1 : $1,000,000)$. SRTM03 matrices have a step of 3 arc seconds, which on the ground corresponds to $90 \mathrm{~m}$ along the meridian and a scale of 1: 100,000. Most of the work is done in QGIS in conjunction with GRASS GIS. Some operations are more convenient to perform in other computer applications. For example, shaded relief maps or in the form of an anaglyph image are more successfully generated in Microdem [6], DEM in axonometric projection in 3DEM [7] or Landserf [8], relief profiles in Microdem or Landserf.

The most productive way to use a DEM is to analyze a volumetric image using an anaglyphic map (an example of an anaglyph map is shown in Fig. 1). Therefore, the following sequence of actions is performed: the matrix is loaded into Microdem, a map is generated there in three versions: anaglyphic, as well as shaded color and gray. These images are saved in GeoTiff format with georeferencing information in the header. Then they are loaded into QGIS, where thematic vector maps and schemes are created from the anaglyph image. For data output, a different basis is used: shaded ("flat") bump maps, colored or, more often, in a gray palette.

The interpretation of the DEM is based on the concept of tectonic flows $[9,10,11]$, adapted for the East Asia region [12]. The main part of the work was carried out with a large-scale DEM 1: 100,000 based on the SRTM03 DEM. It was used to calculate and build: a map of selective contours of the relief; a volumetric relief map in the form of an anaglyphic image; with their help, a map of the relief lineaments was compiled (Fig. 2). The distribution areas of metagabbro and the zones of mineralization and ore bodies located in them were plotted on the maps (based on materials by V.A. Guryanov [3]) Based on the entire set of data, a morphotectonic map of the region and adjacent areas was compiled (Fig. 3).

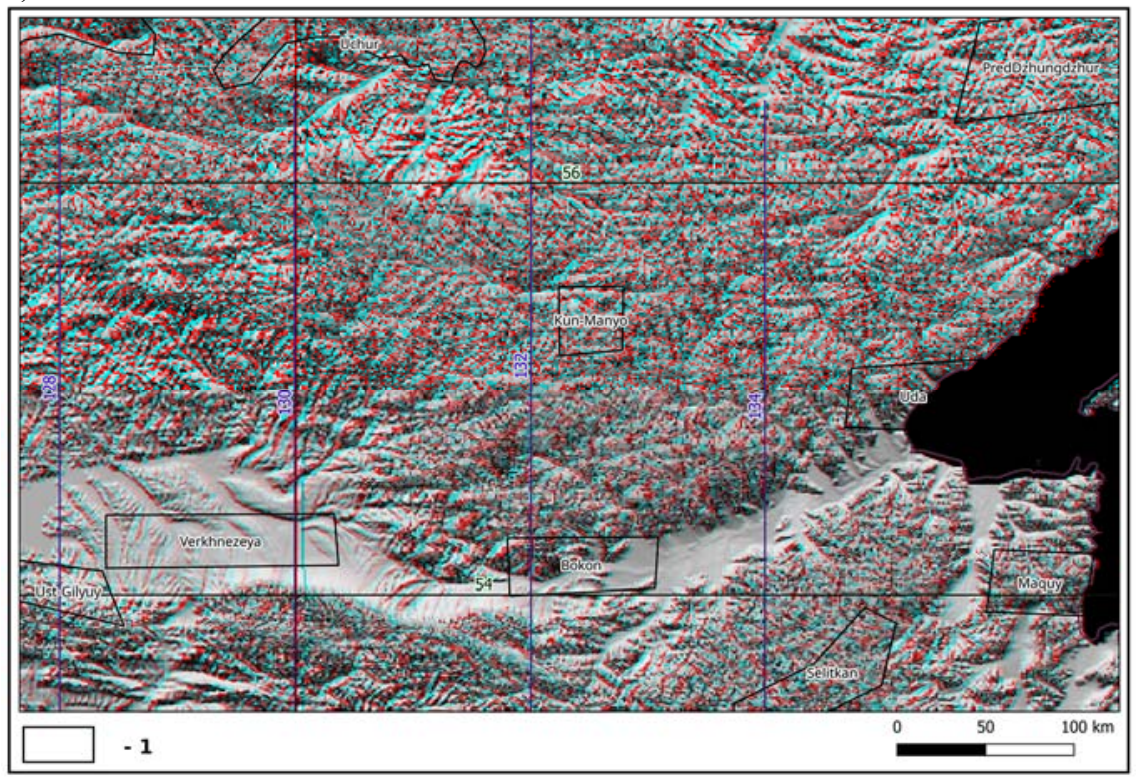

Fig.1. DEM of a part of the Far east - region based on the SRTM30 DEM, visualized as an anaglyph elevation map. 1 - the various sites 


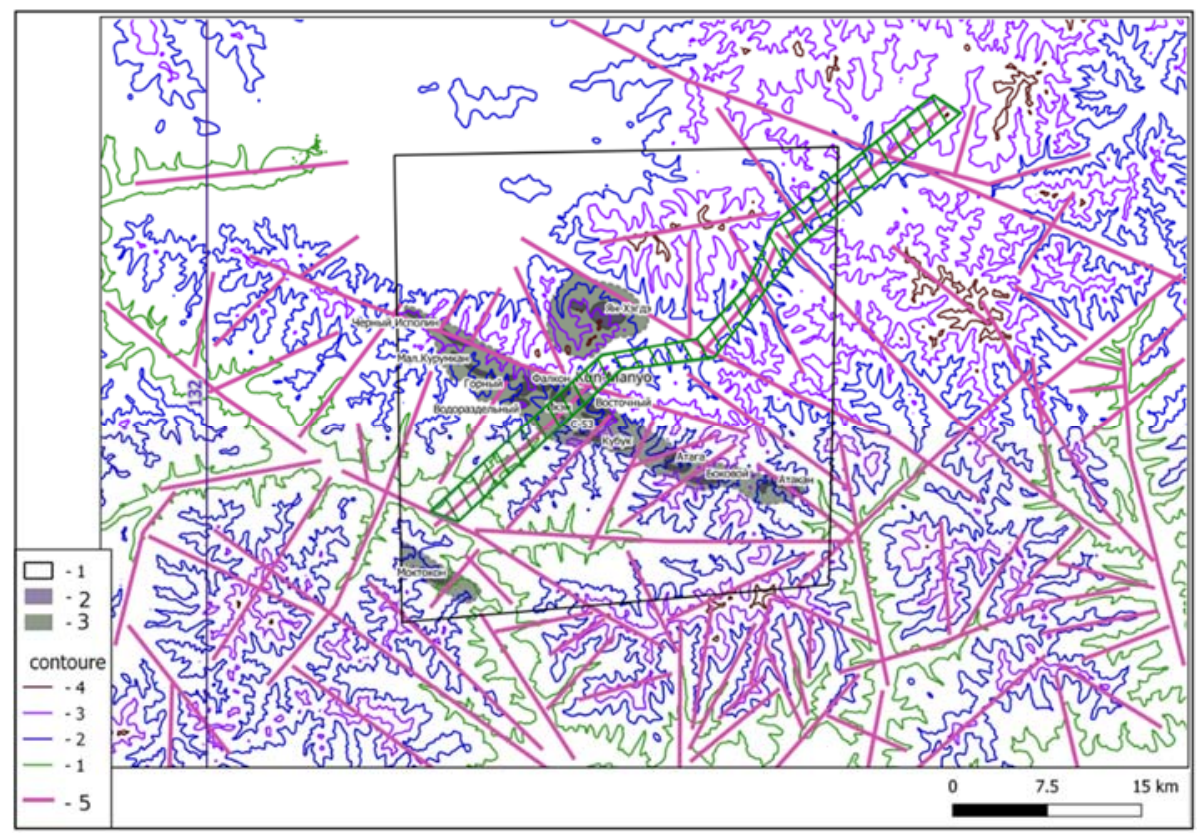

Fig. 2. Plan of the location of the Kun-Manye ore bodies. Basis: map of sparse contours based on DEM SRTM03. 1 - contour of the ore region, 2 - mafic-ultramafic rocks of the Kun-Manyon complex with sulfide mineralization (ore bodies and deposits), 3 - metagabbro (after V.A.Guryanov, 2012); contoure: 1 - 800 m, $2-1200 \mathrm{~m}, 3-1500 \mathrm{~m}, 4-1800 \mathrm{~m} ; 4$ - relief lineaments. Oblique hatching covers the system-controlling tectonic structure

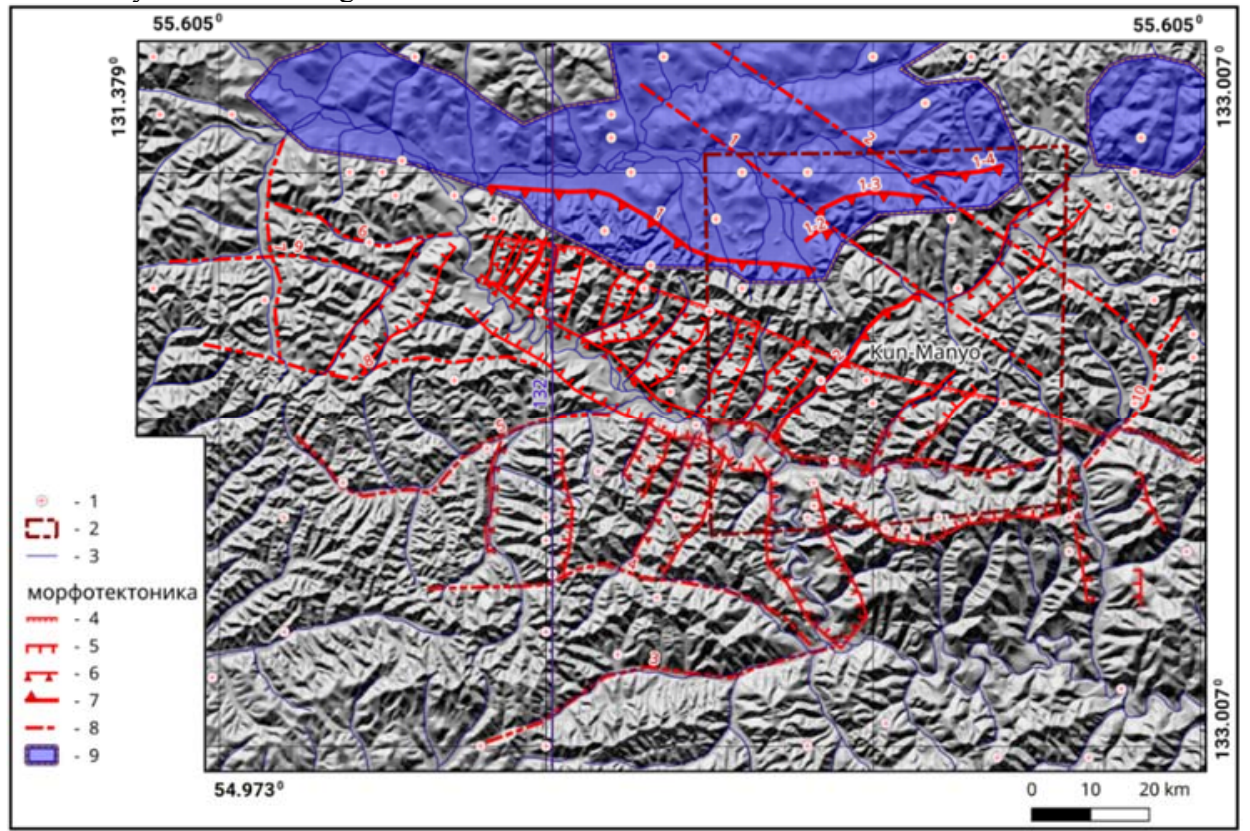

Fig. 3. Morphotectonic scheme of the Kun-Manye ore region and adjacent areas based on the DEM visualized as a shaded relief map (taking into account the data of V.A. 1 - epicenters of earthquakes; 2 - contour of the ore field; 3 - hydraulic network; 4 - discharges; 5 - line of separation of the hanging side from the recumbent reverce thrust; 6 - rear edge of the reverce thrust hanging side; 7 - fronts of thrust faults; 8 - currently active tectonic disturbances of unclear kinematics; 9 - contours of rigid tectonic massivs 


\section{Results and discussion}

The relief lineaments have a significant multidirectionality, although among the most extended one can distinguish a diagonal network: elements of the SE strike, having an average azimuth of approximately $119^{\circ}$ and structures directed almost normal to them, northeast. In fig. 2 and 3, one can also see that over most of the area there is a breaks of the relief. All this indicates a change in the direction of lateral movement of the upper layers of the earth's crust, complicated by chaotic movements of tectonic scales relative to each other. In accordance with the accepted hypothesis, this area is located in the northern part of the Amur tectonic flow [12]. The current drift vector of the tectonic flow is southeast, as evidenced by the predominant direction of the strike of the ridges - depressions and morphostructures intersecting them. In more detail, the method for assessing the direction of movement is described in $[13,14,15$.$] .$

Based on the interpretation, two main cycles of horizontal movements of the tectonic flow can be distinguished in the described area. The first is a submeridional drift in the southern, apparently, direction. Sublatitudinal and submeridional lineaments are indicators of this movement. In some places, they are broken by diagonal structures, which reflect the movement of the second cycle - in the southeast direction, which continues to this day. The results of GPS observations [16] are independent confirmation of the modern drift. Apparently, chaotic fluctuations of individual tectonic scales are superimposed on the general drift. Based on the foregoing, it is natural to assume that the main direction of the horizontal compression vector is southeast. The results of earlier studies in other areas of the Amur Stream suggest that the time of the beginning of the second cycle - the end of the Cretaceous - the beginning of the Paleogene [12].

In the course of work on the study of the relief structure in the region, the presence of rigid tectonic massifs within the limits of tectonic flows was revealed. Visually, on the DEM, they are confidently distinguished as flattened, plateau-like morphostructures within the orogenic belts (areas with a less dissected and smoothed relief in comparison with neighboring, usually surrounding areas). The most clearly such objects are displayed on the anaglyph elevation map, as well as on the contour map. Usually they have no connection with the composition of rocks: they are composed of both igneous and metamorphosed sedimentary, effusive formations. They are split by a system of rare tectonic fractures, which are usually active. Such massifs concentrate and accumulate within themselves and nearby horizontal stresses of a tectonic nature. During the development of deposits located within the limits of their influence, dangerous geodynamic events can be initiated [17].

In the area under consideration, in the northern part of the plate, rigid rock massifs are also distinguished, which are confidently identified by smoothed relief forms. In fig. 2 these are areas with a practical absence of contours. A small massif in the northeastern corner is composed of Proterozoic granites. A large massif located in the northern part of the plate has a complex composition of rocks: granitoids, gneisses, diafluorites, tuffs, metagabbro [3]. It is split by active faults 1 and 2 (in Fig. 3). From the south, during the first cycle, a tectonic cover with front 1 [3] was pulled over it. The cover is deformed by diagonal structures of higher ranks formed as a result of the second cycle. The largest structure of this cycle is indicated by a lineament, which is shown on the plan by oblique shading (Fig. 2). Analysis of the DEM allowed us to assume that the southwestern part of the structure is thrust 2, which along the strike in the NE direction, after the intersecting fault 1 , is replaced by a reverse thrust. Such phenomena are observed in other areas of the tectonic flow [13].

Mineralization is probably concentrated in the zone of influence of a rigid massif. Therefore, it is logical to assess the probability of dangerous geodynamic phenomena during field development as potentially high. Perhaps the diagonal structure described above reduces the influence of the massif to the southeast and this probability decreases. 
One more fact should be noted. The vertical spread of mineralization for different ore bodies varies widely. From 100 m ("Triangle", "Small Kurumkan") to more than 1500 m on the Yan-Khegde section (according to V.A. Guryanov). The interval of relief heights is also significant: $700-1000 \mathrm{~m}$, which can lead to the appearance of an uncompensated horizontal component of geostatic stress.

\section{Conclusion}

The analysis and interpretation of the DEM in the area of the Kurumkansky ore field, which contains the Kun-Manyo copper-nickel deposit, made it possible to identify the main tectonic structures that affect the geodynamic regime of the territory. The field is located within the Amur tectonic flow, drifting in the SE direction. The main structural element that determines its geodynamics is a rigid tectonic massif. Such massifs usually concentrate and accumulate horizontal stresses of a tectonic nature within themselves and nearby. And the stress-strain state of rocks provokes dangerous geodynamic events during the development of mineral deposits. Therefore, the object should be classified as potentially hazardous. As a consequence, it is necessary to carry out a special cycle of work to assess this hazard.

\section{References}

1. V.A. Gur'yanov, V.S. Prikhod'ko, A.N. Perestoronin, L.L. Petukhova, YU.P. Pototskiy, L.P. Sobolev, Doklady Akademii nauk, 425(4), 505 - 508 (2009)

2. V.A. Gurianov, V.S. Prikhodko, V.I. Gvosdev, A.N. Perestoronin, L.L. Petukhova, Platinum of Russia. Colltction of Transactions. VII, 435-448 (2011)

3 A.YU. Peskov, A.N. Didenko, V.A. Gur'yanov, Tikhookeanskaya geologiya, 37(5), 3-15 (2018)

4 V. A. Gur'yanov, V. S. Prikhod'ko, A.YU. Peskov, L.L. Petukhova, A.N. Perestoronin, A.V. Kosynkin, Otechestvennaya geologiya, 6, 48 - 55 (2014)

5. [Elektronnyy resurs] https://dds.cr.usgs.gov/srtm/version2_1/ (srtm03 v1,2.1, srtm30)

6. [Elektronnyy resurs]

https://www.usna.edu/Users/oceano/pguth/website/microdem/microdem.htm

7. [Elektronnyy resurs] http://www.hangsim.com/3dem/

8. [Elektronnyy resurs] http://www.staff.city.ac.uk/ jwo/landserf/download/

9. Lateral'nyye tektonicheskiye potoki v litosfere Zemli Otv. red. M.G. Leonov - M.: GEOS, 318 s. (Tr. GIN RAN; Vyp. 604, 2013)

10. Ye.I. Patalakha, A.M. Lukiyenko, V.V. Gonchar, Tektonicheskiye potoki kak osnova ponimaniya geologicheskikh struktur. Kiyev: Feniks, 160 p. (1995)

11. A.V. Smirnov, Geodinamika formirovaniya podvizhnykh poyasov Zemli. Materialy mezhdunarodnoy nauchnoy konferentsii. Yekaterinburg: Institut geologii i geokhimii UrO RAN, 285-289 (2007)

12. V.I. Usikov, Tektonika, magmatizm i geodinamika Vostoka Azii: VII Kosyginskiye chteniya: materialy vserossiyskoy konferentsii, 12-15 sentyabrya 2011, g. Khabarovsk/otv. red. A.N. Didenko, YU.F. Manilov. - Khabarovsk: ITiG im.YU.A. Kosygina DVO RAN, 328 - 331 (2011)

13. V.I. Usikov, Russian Journal of Pacific Geology. 5(6), $492-508$ (2011)

14. I.YU. Rasskazov, B.G. Saksin, M.I. Potapchuk, V.I. Usikov, Fiziko-tekhnicheskiye problemy razrabotki poleznykh iskopayemykh, 1, 13-22 (2014)

15. I.YU. Rasskazov, B.G. Saksin, V.A. Petrov, B.F. Shevchenko, V.I.Usikov, G.Z. Gil'manova, Fizika Zemli, 3, 144-153 (2014)

16. S.V. Ashurkov, Geologiya i geofizika, 57(11), 2059-2070 (2016) 
17. I.YU. Rasskazov, V.I. Usikov, B.G. Saksin, Tektonika, glubinnoye stroyeniye $i$ minerageniya Vostoka Azii. materialy Vserossiyskoy konferentsii s mezhdunarodnym uchastiyem. Federal'noye gosudarstvennoye byudzhetnoye uchrezhdeniye nauki Inststitut tektoniki i geofiziki im. YU.A. Kosygina DVO RAN Dal'nevostochnogo otdeleniya Rossiyskoy Akademii nauk. 300-302 (2019) 